\title{
Beta-lactamase antimicrobial resistance in Klebsiella and Enterobacter species isolated from healthy and diarrheic dogs in Andhra Pradesh, India
}

\author{
N. Mohammad Sharif, B. Sreedevi, R. K. Chaitanya and D. Sreenivasulu \\ Department of Veterinary Microbiology, College of Veterinary Science, Sri Venkateswara Veterinary University, Tirupati, \\ Andhra Pradesh, India. \\ Corresponding author: N. Mohammad Sharif, e-mail: sharifnoorbasha@gmail.com \\ Co-authors: BS: bollinisreedevi@rediffmail.com, RKC: chaitanyaerk@gmail.com, DS: dsreenivasulu10@gmail.com \\ Received: 05-05-2017, Accepted: 26-07-2017, Published online: 20-08-2017
}

doi: 10.14202/vetworld.2017.950-954 How to cite this article: Sharif NM, Sreedevi B, Chaitanya RK, Sreenivasulu D (2017) Beta-lactamase antimicrobial resistance in Klebsiella and Enterobacter species isolated from healthy and diarrheic dogs in Andhra Pradesh, India, Veterinary World, 10(8): 950-954.

\begin{abstract}
Aim: The aim of this study was to characterize beta-lactamase antimicrobial resistance in Klebsiella and Enterobacter species isolated from healthy and diarrheic dogs in Andhra Pradesh.

Materials and Methods: A total of 136 rectal swabs were collected from healthy (92) and diarrheic (44) dogs, bacteriological cultured for Klebsiella and Enterobacter growth and screened for beta-lactamase antimicrobial resistance phenotypically by disc diffusion method and genotypically by polymerase chain reaction targeting bla ${ }_{\mathrm{TEM}}$, bla $_{\mathrm{SHV}}$, bla $_{\mathrm{OXA}}$, bla $a_{\mathrm{CTX}-\mathrm{M}}$ Group 1,2 , bla ${ }_{\mathrm{AmpC}}$, bla $a_{\mathrm{ACC}}$, and $b l a_{\mathrm{MOX}}$ genes.

Results: A total of 33 Klebsiella and 29 Enterobacter isolates were recovered. Phenotypic beta-lactamase resistance was detected in $66.6 \%$ and $25 \%$ of Klebsiella and Enterobacter isolates, respectively, from healthy dogs and $66.6 \%$ and $60 \%$ of Klebsiella and Enterobacter isolates, respectively, from diarrheic dogs. Overall, incidence of extended-spectrum betalactamase (ESBL) phenotype was found to be 21.2\% (7/33) in Klebsiella isolates, whereas none of the Enterobacter isolates exhibited ESBL phenotype. Predominant beta-lactamase genes detected in Klebsiella species include bla ${ }_{\mathrm{SHV}}(84.8 \%)$, followed by bla TEM $(33.3 \%)$, bla $a_{\text {СтX-м }}$ Group $1(15.1 \%)$, and bla ${ }_{\text {OХА }}(6.1 \%)$ gene. Predominant beta-lactamase genes detected in Enterobacter species include bla SHV $(48.2 \%)$, followed by bla ${ }_{\mathrm{TEM}}(24.1 \%)$, bla $_{\mathrm{AmpC}}(13.7 \%)$, and bla $_{\mathrm{OXA}}(10.3 \%)$ gene.
\end{abstract}

Conclusion: The present study highlighted alarming beta-lactamase resistance in Klebsiella and Enterobacter species of canine origin in India with due emphasis as indicators of antimicrobial resistance.

Keywords: beta-lactamase resistance, dogs, Enterobacter, extended-spectrum beta-lactamase, Klebsiella.

\section{Introduction}

Emergence of multidrug resistance among Enterobacteriaceae members isolated from companion animals has increased substantially over the past 20 years [1]. One resistance mechanism that is of particular concern is that mediated by a family of bacterial enzymes called beta-lactamases that confer resistance to beta-lactam antibiotics [2]. Betalactamase antimicrobial resistance typically develops as a consequence of selective pressure exerted by misuse of cephalosporins [2].

Gut microbiota acts as an ideal reservoir of antimicrobial resistance genes [1]. Overuse and misuse of antimicrobials disrupt normal gut microbiota and select resistant bacteria, leading to enrichment of antibiotic resistant populations inside gut and emergence of so-called "superbugs" [1]. Extended-spectrum beta-lactamases (ESBLs) are

Copyright: Sharif, et al. Open Access. This article is distributed under the terms of the Creative Commons Attribution 4.0 International License (http://creativecommons.org/licenses/by/4.0/), which permits unrestricted use, distribution, and reproduction in any medium, provided you give appropriate credit to the original author(s) and the source, provide a link to the Creative Commons license, and indicate if changes were made. The Creative Commons Public Domain Dedication waiver (http://creativecommons.org/ publicdomain/zero/1.0/) applies to the data made available in this article, unless otherwise stated. variants of beta-lactamases that confer resistance to the third-generation cephalosporins such as cefotaxime, ceftazidime, and ceftriaxone as well as to monobactams such as aztreonam [2]. Beta-lactamase production is mediated by beta-lactamase (bla) genes carried on a plasmid or on the chromosome [2]. Over the past few years, production of beta-lactamases among Gram-negative organisms has increased drastically, especially among the members of Enterobacteriaceae [1,3,4]. Investigating the level of resistance among commensal Enterobacteriaceae was considered as a good indicator of the prevalence of antimicrobial resistance [5].

Although there are reports of phenotypic and genotypic detection of beta-lactamase antimicrobial resistance in farm animals and poultry from India, only a few studies were undertaken in dogs. Keeping in view the above, the present study was conducted with an objective of detection of beta-lactamase antimicrobial resistance in Klebsiella and Enterobacter species isolated from healthy and diarrheic dogs.

\section{Materials and Methods}

\section{Ethical approval}

Ethical approval was not necessary for this study. However, samples were collected as per standard 
collection procedure without harming or giving stress to the animals.

\section{Reference strains}

Beta-lactamase-positive strain of Klebsiella pneumoniae (American Type Culture Collection [ATCC] 700603) and beta-lactamase-negative strain of $E$. coli (ATCC 25922) were used as controls in this study.

\section{Collection and processing of samples}

A total of 136 rectal swab samples were collected from healthy $(n=92)$ and diarrheic $(n=44)$ dogs. Isolation and identification of Klebsiella and Enterobacter species were carried out by conventional cultural methods and biochemical tests [6]. Whole-cell DNA was extracted by boiling and snap chilling method [7]. The absorbance of the DNA at wavelengths $260 \mathrm{~nm}$ and $280 \mathrm{~nm}$ was measured using Nanodrop (Thermo Scientific, USA).

\section{Phenotypic screening for beta-lactamase resistance}

Klebsiella and Enterobacter isolates were subjected to antibiotic sensitivity testing by disc diffusion method on Mueller-Hinton agar [8]. Inhibition zone diameters were interpreted according to the Clinical and Laboratory Standards Institute (CLSI) guidelines $[9,10]$. CLSI recommends two-step procedure for the phenotypic detection of ESBL production, which includes an initial "screening test" to detect resistance against one or more indicator substrates followed by "confirmatory test" using one or more of the indicator substrates in combination with a beta-lactamase inhibitor, looking for synergy effects. Isolates were screened for resistance against four indicator antimicrobial agents: Cefotaxime (CTX, $30 \mu \mathrm{g})$, ceftazidime (CAZ, $30 \mu \mathrm{g})$, ceftriaxone (CTR, $30 \mu \mathrm{g})$, and aztreonam (AT, $30 \mu \mathrm{g}$ ). Resistance to at least one of the indicator antibiotics was considered as "positive" screening test $[9,10]$.

\section{Phenotypic confirmation of ESBL production}

Screening test positive isolates were subjected to "confirmatory test" by combination disc method. Three pairs of discs (i.e., with and without beta-lactamase inhibitor) were placed: Ceftazidime (CAZ, $30 \mu \mathrm{g})$, ceftazidime plus clavulanic acid (CAC, 30/10 $\mu \mathrm{g})$, cefotaxime (CTX, $30 \mu \mathrm{g}$ ), cefotaxime plus clavulanic acid $(\mathrm{CEC}, 30 / 10 \mu \mathrm{g})$ and ceftriaxone (CTR, $30 \mu \mathrm{g})$, and ceftriaxone plus sulbactam (CIS, 30/10 $\mu \mathrm{g}$ ). An isolate was confirmed for ESBL production when the inhibition zone diameter around combination discs was $\geq 5 \mathrm{~mm}$ (synergy effect) when compared to discs containing respective cephalosporin alone $[9,10]$.

\section{Molecular detection of beta-lactamase (b/a) genes}

Three multiplex polymerase chain reaction (PCR) assays [11] and a single uniplex PCR [12] were standardized for the detection of beta-lactamase genes. The use of positive (positive DNA) and negative (nuclease free water) controls was adhered to in all the PCR assays. Oligonucleotide primers (M/s. Eurofins Genomics India Pvt. Ltd., Bengaluru, India) used, and their respective amplicon sizes were given in Table-1. All the other reagents used in the PCR assays were of Genei ${ }^{\mathrm{TM}}$, Bengaluru, India.

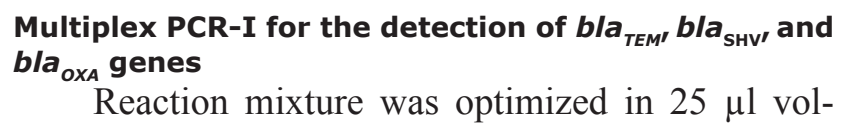
ume containing $2 \mu \mathrm{l}$ of DNA template prepared from each isolate; Taq buffer $(\times 10)-3 \mu 1$; deoxynucleotide triphosphates (dNTPs) mix $(10 \mathrm{mM})-1 \mu \mathrm{l}$; $\mathrm{MgCl}_{2}(25 \mathrm{mM})$ - $1.5 \mu \mathrm{l}$; three forward primers

Table-1: Oligonucleotide primers used for the detection of beta-lactamase genes.

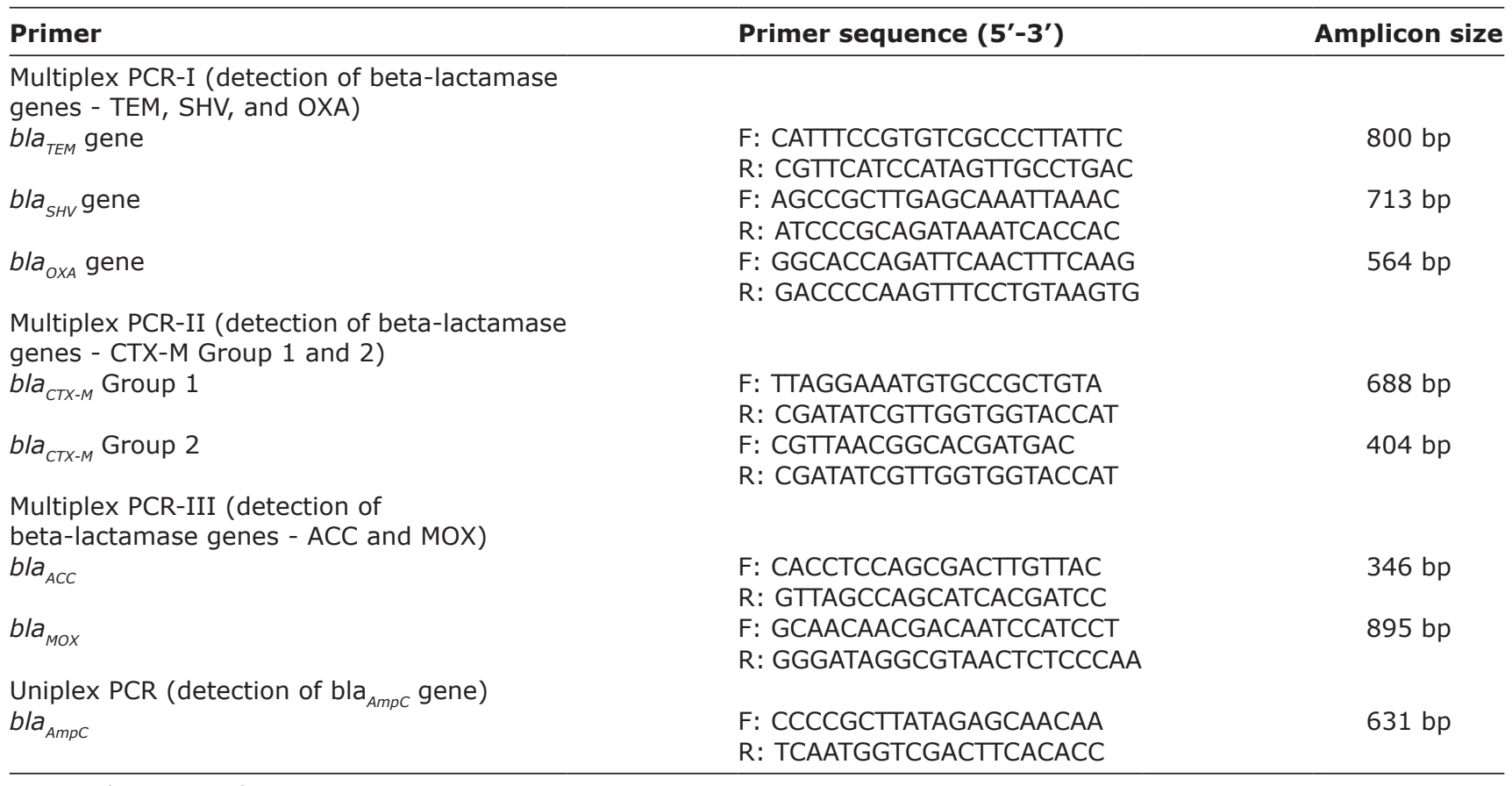

$\mathrm{PCR}=$ Polymerase chain reaction

Veterinary World, EISSN: 2231-0916 
$(10 \mathrm{pmol} / \mu \mathrm{l})$ - each $0.5 \mu \mathrm{l}$; three reverse primers $(10 \mathrm{pmol} / \mu \mathrm{l})$ - each $0.5 \mu \mathrm{l}$; Taq DNA polymerase $(1 \mathrm{U} / \mu \mathrm{l})-1 \mu \mathrm{l}$; and nuclease free water - $13.5 \mu \mathrm{l}$.

\section{Multiplex PCR-II for the detection of bla $_{c T X-M}$ Group 1 and 2 genes}

Reaction mixture was optimized in $25 \mu 1$ volume containing $1.5 \mu \mathrm{l}$ of DNA template prepared from each isolate; Taq buffer $(\times 10)-2.75 \mu \mathrm{l}$; dNTP $\operatorname{mix}(10 \mathrm{mM})-0.5 \mu \mathrm{l} ; \mathrm{MgCl}_{2}(25 \mathrm{mM})-1 \mu \mathrm{l}$; two forward primers $(10 \mathrm{pmol} / \mu \mathrm{l})$ - each $0.75 \mu \mathrm{l}$; two reverse primers $(10 \mathrm{pmol} / \mu \mathrm{l})$ - each $0.75 \mu \mathrm{l} ; \mathrm{Taq}$ DNA polymerase $(1 \mathrm{U} / \mu \mathrm{l})-1 \mu \mathrm{l}$; and nuclease free water $-15.25 \mu 1$.

\section{Multiplex PCR-III for the detection of $b / a_{A C C}$ and bla $_{\text {мох }}$ genes}

Reaction mixture was optimized in $25 \mu 1$ volume containing $2 \mu \mathrm{l}$ of DNA template prepared from each isolate; Taq buffer $(\times 10)-2.75 \mu \mathrm{l}$; dNTP mix $(10 \mathrm{mM})-1 \mu \mathrm{l} ; \mathrm{MgCl}_{2}(25 \mathrm{mM})-1.5 \mu \mathrm{l}$; two forward primers $(10 \mathrm{pmol} / \mu \mathrm{l})$ - each $0.6 \mu \mathrm{l}$; two reverse primers $(10 \mathrm{pmol} / \mu \mathrm{l})$ - each $0.6 \mu \mathrm{l}$; Taq DNA polymerase $(1 \mathrm{U} / \mu \mathrm{l})-1 \mu \mathrm{l}$; and nuclease free water $-14.35 \mu \mathrm{l}$.

All the three multiplex PCR assays were carried out in Kyratec thermal cycler (Australia) under following standardized cycling conditions - initial denaturation at $94^{\circ} \mathrm{C}$ for $10 \mathrm{~min}, 30$ cycles of denaturation at $94^{\circ} \mathrm{C}$ for $40 \mathrm{~s}$, annealing at $60^{\circ} \mathrm{C}$ for $40 \mathrm{~s}$, elongation at $72^{\circ} \mathrm{C}$ for $1 \mathrm{~min}$, final elongation at $72^{\circ} \mathrm{C}$ for 7 min, and hold at $4^{\circ} \mathrm{C}$.

\section{Uniplex PCR assay for the detection of bla $_{\text {Ampc }}$ gene}

The PCR was optimized in $25 \mu$ reaction mixture (containing $1 \mu \mathrm{l}$ of DNA template prepared from each isolate; Taq buffer [×10] - $2.5 \mu \mathrm{l}$; dNTP mix [10 mM] - $0.5 \mu \mathrm{l} ; \mathrm{MgCl}_{2}$ [25 mM] - $1.5 \mu \mathrm{l}$; forward primer $[10 \mathrm{pmol} / \mu \mathrm{l}]-1 \mu \mathrm{l}$; reverse primer $[10 \mathrm{pmol} / \mu \mathrm{l}]-1 \mu \mathrm{l}$; Taq DNA polymerase $[1 \mathrm{U} / \mu \mathrm{l}]-1 \mu \mathrm{l}$; and nuclease free water - $16.5 \mu 1$ ) under the following standardized cycling conditions: Initial denaturation of $94^{\circ} \mathrm{C}$ for $5 \mathrm{~min}$, followed by 30 cycles of denaturation at $94^{\circ} \mathrm{C}$ for $30 \mathrm{~s}$, annealing at $58^{\circ} \mathrm{C}$ for $30 \mathrm{~s}$, and extension at $72^{\circ} \mathrm{C}$ for $30 \mathrm{~s}$. Final extension was done at $72^{\circ} \mathrm{C}$ for $10 \mathrm{~min}$.

\section{Results and Discussion}

\section{Isolation and identification}

On analysis of 136 rectal swab samples, a total of 33 (24.2\%) Klebsiella and 29 (21.3\%) Enterobacter isolates were recovered. From healthy dogs (92), $24(26 \%)$ Klebsiella and Enterobacter isolates each were recovered. From diarrheic dogs (44), 9 (20.4\%)
Klebsiella and $5(11.3 \%)$ Enterobacter isolates were recovered. In a study from Wisconsin (USA), Klebsiella and Enterobacter species were isolated from $57.1 \%$ and $42.8 \%$ of healthy dog fecal samples examined, respectively [13]. In a study from Chhattisgarh (India), Klebsiella species were isolated from $12 \%$ and $35 \%$ of healthy and diarrheic dog fecal samples, respectively [14]. Observed variation in the proportion of isolation across studies might be due to various variables such as genetic determinants, diet, environment, and age.

\section{Detection of beta-lactamase resistance}

An overall incidence of $66.6 \%(22 / 33)$ and $31 \%(9 / 29)$ beta-lactamase resistance was detected in Klebsiella and Enterobacter species, respectively. Healthy and diarrheic dogs were isolated, respectively, $16(66.6 \%) / 6(66.6 \%)$ Klebsiella and $6(25.0 \%) / 3(60.0 \%)$ Enterobacter isolates. All these isolates were found to be resistant to one or more of beta-lactam antibiotics indicators and were designated as "suspect ESBL producers." In a study from the Netherlands, $45 \%$ incidence of beta-lactamase resistance was reported in Enterobacteriaceae isolated from pet dogs [15]. Frequency of beta-lactam resistance detected in Klebsiella and Enterobacter isolates recovered in the present study was given in Table-2. Overall, the incidence of resistance to cefotaxime, ceftriaxone, ceftazidime, and aztreonam was found to be $42.4 \%(14 / 33), 36.3 \%(12 / 33), 33.3 \%$ (11/33), and 9.1\% (3/33), respectively, in Klebsiella species. A study from France reported resistance to cefotaxime, ceftazidime, and aztreonam in all the 18 Klebsiella isolates recovered from hospitalized dogs [16]. Overall, the incidence of resistance to cefotaxime, ceftriaxone, and ceftazidime was found to be $24.1 \%(7 / 29), 17.2 \%(5 / 29)$, and $13.7 \%(4 / 29)$, respectively, in Enterobacter species. Aztreonam resistance was not detected in Enterobacter isolates recovered in this study. A study from Australia reported complete resistance to cefotaxime, ceftazidime, and aztreonam in all the 10 Enterobacter isolates recovered from hospitalized dogs [17].

\section{Confirmation of ESBL production}

Among Klebsiella isolates, ESBL production was confirmed in $7(21.2 \%)$ isolates. All these seven isolates were found resistant to at least one of the indicator cephalosporin used in the screening test but were found susceptible to combination of indicator cephalosporin with clavulanic acid or sulbactam in

Table-2: Frequency of beta-lactam resistance detected in Klebsiella and Enterobacter species.

\begin{tabular}{|c|c|c|c|c|}
\hline \multirow[t]{2}{*}{ Indicator antibiotic } & \multicolumn{2}{|c|}{ Klebsiella species } & \multicolumn{2}{|c|}{ Enterobacter species } \\
\hline & Healthy dogs (24) & Diarrheic dogs (9) & Healthy dogs (24) & Diarrheic dogs (5) \\
\hline Cefotaxime & $12(50 \%)$ & $2(22.2 \%)$ & $4(16.6 \%)$ & $3(60 \%)$ \\
\hline Ceftriaxone & $8(33.3 \%)$ & $4(44.4 \%)$ & $3(12.5 \%)$ & $2(40 \%)$ \\
\hline Ceftazidime & $7(29.1 \%)$ & $4(44.4 \%)$ & $3(12.5 \%)$ & $1(20 \%)$ \\
\hline Aztreonam & $2(8.3 \%)$ & $1(11.1 \%)$ & - & - \\
\hline
\end{tabular}


the confirmatory test. As clavulanic acid or sulbactam is beta-lactamase inhibitors, we can conclude that, in these seven isolates, the cephalosporin resistance mechanism could be mediated by beta-lactamase production. Clavulanic acid synergy (5 $\mathrm{mm}$ principle) was not detected in the remaining isolates, which might be due to the concurrent production of other non-ESBL beta-lactamases that confer resistance to beta-lactamase inhibitors $[9,18]$. The observed levels of ESBL phenotype among canine microbiota appeared to range from $1.4 \%$ to $90 \%$ in different studies, i.e., 1.4\% in UK [19], 4\% in Pennsylvania [18], $20 \%$ in Chili [20], 41.3\% in China [21], and 90\% in Australia [17]. ESBL phenotype was not detected in none of the Enterobacter isolates recovered in this study. In contrary, ESBL phenotype was reported in 9 out of 10 Enterobacter isolates recovered from opportunistic infections of dogs in Australia [17]. Difference in observed levels of beta-lactamase resistance and ESBL phenotype across various studies might be due to the variations in the methodology adopted, study population, extent of usage of third-generation cephalosporins, and drug pressure in the community.

\section{Detection of beta-lactamase (b/a) genes}

Detection of resistance genes using nucleic acidbased techniques has been of great use and has been shown to complement phenotypic results [11]. The overall incidence of beta-lactamase genes in Klebsiella and Enterobacter species was found to be $90.9 \%$ $(30 / 33)$ and $72.4 \%(21 / 29)$, respectively. Incidence of beta-lactamase genes in canine microbiota was found to range from $17.5 \%$ to $82.2 \%$ across various studies, i.e., $17.5 \%$ in Tunisia [22], 56.5\% in UK [19], and $82.2 \%$ in the Netherlands [23]. Frequency of beta-lactamase genes detected in Klebsiella and Enterobacter isolates recovered in the present study was given in Table-3. Among the Klebsiella isolates recovered from healthy dogs, one or more beta-lactamase genes were detected in a total of $21(87.5 \%)$ isolates, whereas $3(12.5 \%)$ isolates were found negative for all the genes. Among the Klebsiella isolates recovered from diarrheic dogs, all the isolates carried one or more of the beta-lactamase genes screened for. Overall, the incidence of bla $a_{\mathrm{SHV}}, b l a_{\text {TЕМ }}, b l a_{\text {СТХ-М }}$ Group 1, and bla $a_{\mathrm{OXA}}$ genes was found to be $84.8 \%$, $33.3 \%, 15.1 \%$, and $6.1 \%$, respectively, in Klebsiella species. In a study from France, $b l a_{\mathrm{TEM}}, b l a_{\mathrm{OXA}}$, and $b l a_{\text {СтХ-м }}$ genes were reported to be detected in all the Klebsiella isolates recovered from the dogs [16].

Among the 24 Enterobacter isolates recovered from healthy dogs, one or more beta-lactamase genes were detected in a total of $16(66.6 \%)$ isolates, whereas $8(33.3 \%)$ isolates were found negative for all the genes. Among the 5 Enterobacter isolates recovered from diarrheic dogs, all the isolates carried one or more of the beta-lactamase genes screened for. Overall, the incidence of $b l a_{\mathrm{SHV}}, b l a_{\mathrm{TEM}}, b l a_{\mathrm{AmpC}}$, and $b l a{ }_{\text {OXA }}$ genes was found to be $48.2 \%, 24.1 \%, 13.7 \%$, and $10.3 \%$, respectively, in Enterobacter species. In a study conducted in Australia, bla ${ }_{\mathrm{TEM}}, b l a_{\mathrm{SHV}}$, and bla $a_{\mathrm{OXA}}$ genes were reported to be detected in $100 \%, 90 \%$, and $10 \%$ of the Enterobacter isolates recovered from dogs, respectively [17]. In another study from Lisboa, 5.5\% incidence of bla ${ }_{\mathrm{AmpC}}$ gene was reported in Enterobacter species [24]. The phenotypic resistance to third-generation cephalosporins and monobactams detected in this study supported by its molecular confirmation by the detection of beta-lactamase genes probably indicates the need for careful selection and judicious usage of beta-lactam antibiotics in the treatment of canine infections in this region. The incidence rates are likely to increase further if strict control measures on the usage of third-generation cephalosporins were not implemented.

\section{Conclusion}

This study reporting the beta-lactamase resistance among Klebsiella and Enterobacter species with due emphasis as indicators of antimicrobial resistance adds to the alarming beta-lactamase resistance reports among Enterobacteriaceae members worldwide. The alarming incidence of beta-lactamase resistance detected in this study might probably be the result of indiscriminate usage of third-generation cephalosporins in canine practice, which reflects the possible risk of therapeutic failures that may occur in the treatment of infections caused by Klebsiella and Enterobacter species.

\section{Authors' Contributions}

NMS is the student worked for M.V.Sc. thesis. $\mathrm{BS}$ as major guide and $\mathrm{RKC}$ as minor guide designed and supervised the research work. Manuscript was drafted and revised by NMS under the guidance of $\mathrm{BS}, \mathrm{RKC}$, and DS. All authors read and approved the final manuscript.

Table-3: Frequency of beta-lactamase genes detected in Klebsiella and Enterobacter species.

\begin{tabular}{|c|c|c|c|c|}
\hline \multirow[t]{2}{*}{ Beta-lactamase gene } & \multicolumn{2}{|c|}{ Klebsiella species } & \multicolumn{2}{|c|}{ Enterobacter species } \\
\hline & Healthy dogs (24) & Diarrheic dogs (9) & Healthy dogs (24) & Diarrheic dogs (5) \\
\hline bla $_{T E M}$ & $10(41.6 \%)$ & $1(11.1 \%)$ & $6(25 \%)$ & $1(20 \%)$ \\
\hline bla & $20(83.3 \%)$ & $8(88.8 \%)$ & $9(37.5 \%)$ & $5(100 \%)$ \\
\hline$b l a a_{O X A}$ & $2(8.3 \%)$ & - & $2(8.3 \%)$ & $1(20 \%)$ \\
\hline bla $_{A M P C}$ & - & - & $2(8.3 \%)$ & $2(40 \%)$ \\
\hline bla $_{C T X-M}^{\text {AmpC }}$ Group 1 & $3(12.5 \%)$ & $2(22.2 \%)$ & - & - \\
\hline
\end{tabular}

bla $_{C T X-M}$ Group-2, bla ${ }_{A C C}$ and bla ${ }_{\text {MOX }}$ genes were not detected in the present study 


\section{Acknowledgments}

The authors acknowledge Sri Venkateswara Veterinary University, Tirupati, Andhra Pradesh, for providing necessary funds (grant number 2370/BG/ B1/2016, dated 13-04-2016 of the Comptroller, SVVU, Tirupati to the department of Veterinary Microbiology, College of Veterinary Science, Tirupati) and facilities to carry out the research work.

\section{Competing Interests} interests.

The authors declare that they have no competing

\section{References}

1. Rubin, J.E. and Pitout, J.D. (2014) Extended-spectrum $\beta$-lactamase, carbapenemase and AmpC producing Enterobacteriaceae in companion animals. Vet. Microbiol., 170(1): 10-18

2. Bush, K. and Jacoby, G.A. (2010) Updated functional classification of $\beta$-lactamases. Antimicrob. Agents Chemother, 54(3): 969-976.

3. Stolle, I., Prenger-Berninghoff, E., Stamm, I., Scheufen, S., Hassdenteufel, E., Guenther, S., Bethe, A., Pfeifer, Y. and Ewers, C. (2013) Emergence of OXA-48 carbapenemase-producing Escherichia coli and Klebsiella pneumoniae in dogs. J. Antimicrob. Chemother, 68: 2802-2808.

4. Schaufler, K., Bethe, A., Lübke-Becker, A., Ewers, C., Kohn, B., Wieler, L.H. and Gunther, S. (2015) Putative connection between zoonotic multiresistant extended-spectrum beta-lactamase (ESBL)-producing Escherichia coli in dog feces from a veterinary campus and clinical isolates from dogs. Infect. Ecol. Epidemiol., 5: 25334.

5. Pfeifer, Y., Cullik, A. and Witte, W. (2010) Resistance to cephalosporins and carbapenems in Gram-negative bacterial pathogens. Int. J. Med. Microbiol., 300(6): 371-379.

6. Sneath, P.H.A. and Holt, J.G. (2001) Bergey's Manual of Systematic Bacteriology. $2^{\text {nd }}$ ed., Vol. 1. A Waverly Company, Williams \& Wilkins, Springer-Verlag, NewYork, USA.

7. Wani, S.A., Samanta, I., Munshi, Z.H., Bhat, M.A. and Nishikawa, Y. (2006) Shiga toxin-producing Escherichia coli and enteropathogenic Escherichia coli in healthy goats in India: Occurrence and virulence properties. J. Appl. Microbiol., 100: 108-113.

8. Bauer, A.W., Kirby, W.M.M., Sherris, J.C. and Turck, M. (1966) Antibiotic susceptibility testing by a standardized single disk method. Am. J. Clin. Pathol., 45(4): 493.

9. Drieux, L., Brossier, F., Sougakoff, W. and Jarlier, V. (2008) Phenotypic detection of extended-spectrum $\beta$-lactamase production in Enterobacteriaceae: Review and bench guide. Clin. Microbiol. Infect., 14: 90-103.

10. Clinical and Laboratory Standards Institute, CLSI. (2014) Performance Standards for Antimicrobial Susceptibility Testing: Twenty-Fourth Informational Supplement. M100-S24. Clinical and Laboratory Standards Institute, Wayne, PA, USA.

11. Dallenne, C., da Costa, A., Decré, D., Favier, C. and Arlet, G. (2010) Development of a set of multiplex PCR assays for the detection of genes encoding important $\beta$-lactamases in Enterobacteriaceae. J. Antimicrob. Chemother, 65: 490-495.
12. Shahid, M., Sobia, F., Singh, A. and Khan, H.M. (2012) Concurrent occurrence of blaampC families and blaCTX-M genogroups and association with mobile genetic elements ISEcp1, IS26, ISCR1, and sul1-type class 1 integrons in Escherichia coli and Klebsiella pneumoniae isolates originating from India. J. Clin. Microbiol., 50(5): 1779-1782.

13. Balish, E., Cleven, D., Brown, J. and Yale, C.E. (1977) Nose, throat, and fecal flora of beagle dogs housed in "locked" or "open" environments. Appl. Environ. Microbiol., 34(2): 207-221.

14. Suryawanshi, P.R. and Hirpurkar, S.D. (2008) Antibiogram of enteric and urinary isolates of Pseudomonas, Klebsiella and Proteus sp. from cattle, dogs and pigs. J. Bombay Vet. Coll., 16(1): 3-5.

15. Hordijk, J., Schoormans, A., Kwakernaak, M., Duim, B., Broens, E., Dierikx, C., Mevius, D. and Wagenaar, J.A. (2013) High prevalence of fecal carriage of extended spectrum $\beta$-lactamase/AmpC-producing Enterobacteriaceae in cats and dogs. Front. Microbiol., 4: 242.

16. Haenni, M., Ponsin, C., Metayer, V., Médaille, C. and Madec, J.Y. (2011) Veterinary hospital-acquired infections in pets with a ciprofloxacin-resistant CTX-M-15-producing Klebsiella pneumoniae ST15 clone. J. Antimicrob. Chemother., 67: 770-771.

17. Sidjabat, H.E., Hanson, N.D., Smith-Moland, E., Bell, J.M., Gibson, J.S., Filippich, L.J. and Trott, D.J. (2007) Identification of plasmid-mediated extended-spectrum and AmpC $\beta$-lactamases in Enterobacter spp. isolated from dogs. J. Med. Microbiol., 56(3): 426-434.

18. O'Keefe, A., Hutton, T.A., Schifferli, D.M. and Rankin, S.C. (2010) First detection of CTX-M and SHV extended-spectrum $\beta$-lactamases in Escherichia coli urinary tract isolates from dogs and cats in the United States. Antimicrob. Agents Chemother, 54(8): 3489-3492.

19. Wedley, A.L., Maddox, T.W., Westgarth, C., Coyne, K.P., Pinchbeck, G.L., Williams, N.J. and Dawson, S. (2011) Prevalence of antimicrobial-resistant Escherichia coli in dogs in a cross-sectional, community-based study. Vet. Rec., 168(13): 354.

20. Moreno, A., Bello, H., Guggiana, D., Dominguez, M. and Gonzalez, G. (2008) Extended-spectrum $\beta$-lactamases belonging to CTX-M group produced by Escherichia coli strains isolated from companion animals treated with enrofloxacin. Vet. Microbiol., 129(1): 203-208.

21. Sun, Y., Zeng, Z., Chen, S., Ma, J., He, L., Liu, Y., Deng, Y., Lei, T., Zhao, J. and Liu, J.H. (2010) High prevalence of blaCTX-M extended-spectrum $\beta$-lactamase genes in Escherichia coli isolates from pets and emergence of CTX-M-64 in China. Clin. Microbiol. Infect., 16(9): 1475-1481.

22. Sallem, R.B., Gharsa, H., Slama, K.B., Rojo-Bezares, B., Estepa, V., Porres-Osante, N., Jouini, A., Klibi, N., Sáenz, Y., Boudabous, A. and Torres, C. (2013) First detection of CTX-M-1, CMY-2, and QnrB19 resistance mechanisms in fecal Escherichia coli isolates from healthy pets in Tunisia. Vector Borne Zoonotic Dis., 13(2): 98-102.

23. Baede, V.O., Wagenaar, J.A., Broens, E.M., Duim, B., Dohmen, W., Nijsse, R., Timmerman, A.J. and Hordijk, J. (2015) Longitudinal study of extended-spectrum- $\beta$-lactamase-and AmpC-producing Enterobacteriaceae in household dogs. Antimicrob. Agents Chemother, 59(6): 3117-3124.

24. Sailal, D.C.C. (2013) Use of Antimicrobials and Cephamicin Resistance in Companion Animals. Ph.D. Thesis Submitted to University of Lisboa, Lisbon. 